\title{
How tobacco companies have used package quantity for consumer targeting
}

\author{
Alexander Persoskie, Elisabeth A Donaldson, Chase Ryant
}

- Additional material is published online only. To view please visit the journal online (http://dx.doi.org/10.1136/ tobaccocontrol-2017-053993)

Office of Science, FDA Center for Tobacco Products, Silver Spring, $M D$, USA

\section{Correspondence to} Dr Alexander Persoskie, FDA Center for Tobacco Products Office of Science, Silver Spring, MA 20993,USA; alexander.persoskie@fda.hhs. gov

Received 12 August 2017 Revised 16 April 2018 Accepted 26 April 2018 Published Online First 31 May 2018

\section{Linked}

- http://dx.doi.org/10.1136/ tobaccocontrol-2018-054458

Check for updates

To cite: Persoskie A, Donaldson EA, Ryant C. Tob Control

2019:28:365-373.

\section{ABSTRACT}

Introduction Package quantity refers to the number of cigarettes or amount of other tobacco product in a package. Many countries restrict minimum cigarette package quantities to avoid low-cost packs that may lower barriers to youth smoking.

Methods We reviewed Truth Tobacco Industry Documents to understand tobacco companies' rationales for introducing new package quantities, including companies' expectations and research regarding how package quantity may influence consumer behaviour. A snowball sampling method (phase 1), a static search string (phase 2) and a follow-up snowball search (phase 3) identified 216 documents, mostly from the 1980s and 1990s, concerning cigarettes (200), roll-your-own tobacco (9), smokeless tobacco (6) and 'smokeless cigarettes' (1).

Results Companies introduced small and large packages to motivate brand-switching and continued use among current users when faced with low market share or threats such as tax-induced price increases or competitors' use of price promotions. Companies developed and evaluated package quantities for specific brands and consumer segments. Large packages offered value-for-money and matched long-term, heavy users' consumption rates. Small packages were cheaper, matched consumption rates of newer and lighter users, and increased products' novelty, ease of carrying and perceived freshness. Some users also preferred small packages as a way to try to limit consumption or quit. Conclusion Industry documents speculated about many potential effects of package quantity on appeal and use, depending on brand and consumer segment. The search was non-exhaustive, and we could not assess the quality of much of the research or other information on which the documents relied.

\section{INTRODUCTION}

Tobacco package quantity refers to the number of cigarettes or cigars, the amount of smokeless tobacco (SLT) or the quantity of other product in a package. Local, state and national governments have passed laws limiting tobacco package quantities because of concerns that package quantity can influence tobacco use (21 CFR $1140.16,{ }^{1-5} \mathrm{p}$. $\left.168,{ }^{6}\right)$. In the USA, it is illegal to sell cigarette packages with fewer than 20 cigarettes, a restriction enacted in most states by the Master Settlement Agreement (1998-2001) and later by federal law (21 CFR 1140.16). A small but growing number of laws restrict minimum package quantities for non-cigarette tobacco products such as cigars $\left(\mathrm{eg},{ }^{1-3}\right)$, and few laws restrict maximum package quantities.
The rationale for restricting minimum tobacco package quantities is that small packages may lower barriers to use by children. ${ }^{25-7}$ Critics have used the term 'kiddie pack' to refer to cigarette packs with fewer than 20 sticks $^{78}$ and roll-your-own (RYO) tobacco packages with less than $16.8 \mathrm{~g}$ of tobacco, ${ }^{9}$ arguing that such packages are designed for youth who are on a tight budget or must conceal the product from adults. ${ }^{10}$ Indeed, a 2006 study in Ireland found that youth smokers (aged 12-17) tended to buy cigarettes in packs of $10(76 \%)$, whereas young adults (age 18-24) and older adults (age $25+$ ) tended to buy cigarettes in packs of 20 (60\% and 77\%, respectively) ( ${ }^{11}$, p. 24). A 1987 study also found that smokers aged 14 and 15 years in one Australian community were more likely than adult smokers to report purchasing cigarettes in a 15 -pack (56\% vs $9 \%$, respectively). ${ }^{10}$

Aside from these suggestive results, little research has evaluated how package quantity influences tobacco product use or appeal. A recent systematic review of published research on the effects of tobacco package quantity, size and shape on consumption found only three eligible studies, all of which concerned cigarette length. ${ }^{12}$

Given the dearth of published information, we examined tobacco companies' previously secret internal documents concerning tobacco package quantity. Millions of industry documents are publicly available in the Truth Tobacco Industry Documents (TTIDs). ${ }^{13}{ }^{14} \mathrm{Few}$ studies have examined documents on package quantity, and only in passing. ${ }^{15-17}$ We conducted a review of industry documents to understand tobacco companies' rationales for changing or introducing new package quantities, including their expectations and research regarding how package quantity may influence consumer behaviour.

\section{METHODS}

We searched the TTID in three phases (see table 1). In phase 1, we used a standard snowball sampling technique $^{18}$ typical for industry document reviews (eg, $\left.{ }^{19-21}\right)$. In phase 2 , we searched a single string of terms. In phase 3 , we conducted a follow-up snowball search of additional terms and strings based on documents found in phase 2. In each phase, we identified documents for full-text review if the title or first few pages contained information about research on package quantity or stated a reason for choosing or changing a package quantity; this is opposed to, for example, invoices simply listing products. We reviewed the full text of potentially relevant documents. The search was not limited to consumer research documents, nor was it limited to any particular tobacco product type or geographic 


\begin{tabular}{|c|c|c|c|}
\hline Phase & Technique & Procedure & Search dates \\
\hline Phase 1 & Snowball sampling & 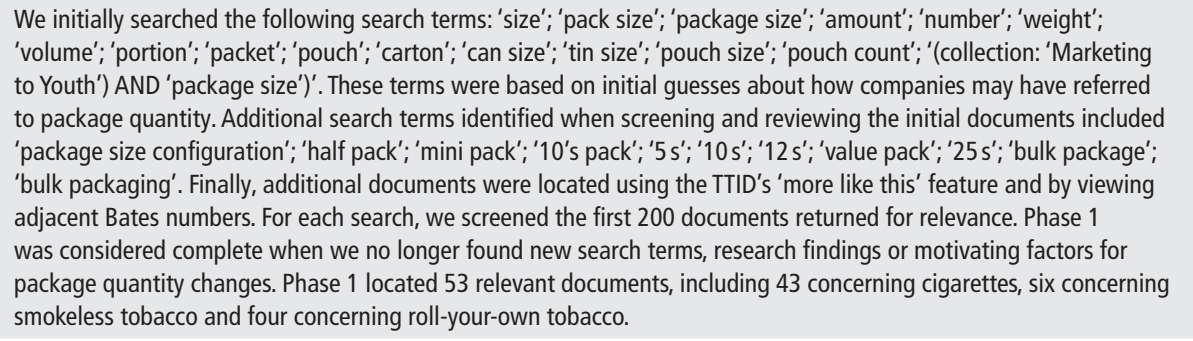 & $\begin{array}{l}15 \text { June } 2015 \text { to } 27 \\
\text { April } 2016\end{array}$ \\
\hline Phase 2 & Static search & $\begin{array}{l}\text { We entered the following search string on September 22, 2017: ((" pack size" OR "package size" OR "can size" OR } \\
\text { "tin size" OR "pouch count") AND ("half pack" OR "mini pack" OR "bulk pack" OR "Project Orville" OR "Project } \\
\text { Buck" OR "kiddie pack" OR "Project Silver" OR "Craven A" OR "Packaging Evaluation Study" OR "Black Smoker } \\
\text { Study" OR "10-pack" OR "10's" OR "5-pack" OR "5's" OR "12-pack" OR "12's" OR "14-pack" OR "14's" OR } \\
\text { "15-pack" OR "15's" OR "25-pack" OR "25's")) AND ("plan" OR "report" OR "evaluation")) NOT ("invoice" OR } \\
\text { "compliance report" OR "distribution summary" OR "purchase order" OR "docket" OR "product analytical" OR } \\
\text { "Cigarette Information Report"). The search returned 3311 results. We screened all of these documents for relevance. } \\
\text { Phase } 2 \text { located } 113 \text { relevant documents that were not covered in phase 1, including } 112 \text { concerning cigarettes and } \\
\text { one concerning 'smokeless cigarettes.' }\end{array}$ & $\begin{array}{l}18 \text { September to } 28 \\
\text { October } 2017\end{array}$ \\
\hline Phase 3 & $\begin{array}{l}\text { Follow-up snowball } \\
\text { search of additional } \\
\text { terms }\end{array}$ & $\begin{array}{l}\text { We searched the following terms and strings, plus the adjacent Bates numbers of any relevant documents located: } \\
\text { "black smoker study" and "10 pack"; "Project Orville"; "Project Buck"; "Project Silver"; "pack size" AND ("consumer } \\
\text { pull-out" OR "consumer pullout"); "15's format"; "cigarette segmentation study" AND "pack size"; "pack size" } \\
\text { AND "rationing"; title:("pack size"); title:("trial pack"); "pack size starter" 20; "package size starter" 20; "pack } \\
\text { size consumption" } 10 \text { NOT "docket" NOT "commons" NOT "american society"; "buying habits study" AND } \\
\text { ("pack size" OR "package size"); "buyer's study" AND "pack size"; "Packaging Evaluation Study"; "Black Smoker } \\
\text { Study" AND "package size"; "Black Smoker Study" AND "pack size"; "Rationalisation of Pack Size"; "Package Size } \\
\text { Evaluation Study"; "Package Size Test"; "12-count pack"; "Pack Size Dynamics"; "Project Delta" AND "pack size"; } \\
\text { "new consumers/YAS" AND "pack size"; title:("10's pack"); title:("12-pack"); title:" van program" AND "10 pack"; } \\
\text { title:" package size". The searches returned approximately } 800 \text { documents in total. We screened all of these documents } \\
\text { for relevance. Phase } 3 \text { located } 50 \text { relevant documents that were not covered in phases } 1 \text { or 2, including } 45 \text { documents } \\
\text { on cigarettes and five documents on roll-your-own tobacco. }\end{array}$ & $\begin{array}{l}19 \text { January } 19 \text { to } \\
22 \text { February } 2018\end{array}$ \\
\hline
\end{tabular}

location. We restricted the search to documents from 1980 or later to focus on more recent documents. For all relevant documents, we wrote a short summary and extracted information concerning reasons why a company may choose a particular package quantity for one of its products, and research on whether (or why) consumers may use particular package quantities. All authors participated in summarising documents; the first author read all document summaries and viewed all documents to identify emergent themes.

\section{RESULTS}

\section{General findings}

We identified 216 unique documents (see online supplementary table for descriptions) including research reports, memos and presentations $(\mathrm{n}=88)$; memos describing product ideas, marketing plans and marketing decision rationales $(n=112)$; and miscellaneous documents including speech scripts, retailer packets, and trade magazine and news articles $(n=16)$. Much of the consumer research was qualitative; documents describing quantitative research generally did not provide significance tests or effect sizes. Documents included information from the USA as well as Australia, Belgium, Canada, France, Germany, Japan, Korea, Malaysia, Paraguay and others. Most documents concerned cigarettes $(n=200)$, with the remainder on RYO tobacco $(n=9)$, SLT $(n=6)$ and 'smokeless cigarettes' $(n=1){ }^{1}$ Dates ranged from 1980 to 2009 , with most from the 1980 s $(n=117)$ and 1990s $(n=88)$, and the remainder from the 2000s $(\mathrm{n}=11)$.

Companies did not regard either small or large packages as universally superior. Rather, documents discussed the suitability of package quantity changes for specific brands, markets and consumer segments. For example, research evaluated consumers' reasons for liking particular cigarette package quantities separately by brand ${ }^{22-25}$ and among smokers differing in attitudes and psychographic characteristics. ${ }^{26-34}$ For non-value brands, large packages could potentially detract from perceived quality. ${ }^{26} 2833$ Cigarette brands with low proportions of 'committed' users were viewed as more price-sensitive and vulnerable to competitors' use of package quantity changes to stimulate brand-switching. ${ }^{34}$ Smokers were classified into segments such as commodity smokers ('price is everything') and contemporaries (smokers concerned about health effects), with commodity smokers preferring large packages and contemporaries averse to them. ${ }^{29}$ Documents acknowledged that consumer characteristics and preferences change over time. ${ }^{29} 35-38$

\section{Package quantity constraints}

Companies were constrained in their ability and willingness to change package quantities. For cigarettes, some jurisdictions banned 'sample-pack' sizes, ${ }^{39} 40$ and tax laws created logistical challenges and price penalties for non-standard quantities. ${ }^{39}$ 41-44 Package quantity changes sometimes required converting or buying new packing machinery. ${ }^{45-50}$ Before launching a product in a new package quantity, companies considered the risk that the product would cannibalise the market share of their other products. ${ }^{32} 495152$ Package quantity changes could also provoke negative reactions from competitors such as price wars. ${ }^{35} 3853-56$ Companies seemed to initiate quantity changes in markets where a brand had low or declining market share, ${ }^{35} 375257-62$ or where competitors 
threatened to gain market share using novel package quantities or price cuts. ${ }^{51535562-77}$

\section{Price, affordability and value}

A key reason why companies changed package quantities was to influence consumer behaviour through effects on price. ${ }^{35}$ Smaller packages could be sold for lower per-package prices, ${ }^{23} 323641424951$ $5354575860616366-7174-7678-132$ and large packages provided per-unit value. $^{25293638424550525355-5961-6573839091117119122128133-182}$

Small, low-priced packages were aimed at stimulating purchase by users of competitor brands and maintaining the brand's current user base. ${ }^{23} 32364142495153545758606163$ 66-7174-76 ${ }^{78-132}$ For example, one document recommended introducing a 10-pack of Raffles cigarettes to 'facilitate trial, particularly by younger smokers', and to avoid losing Raffles' current smokers to competitors' 10 -pack offerings. ${ }^{49}$ In qualitative research, some smokers viewed a 10-pack as 'an 'introductory' or 'trial pack' offer' that 'provides a 'low price' way to 'experiment' with a new brand'. ${ }^{81}$ Similarly, cigarette research in Belgium found that "St. Michel 20's should be able to attract more new users than St. Michel 25's because of the overall lower per pack price". ${ }^{23}$ The 20-pack was also estimated to have a lower price elasticity than the 25 -pack, meaning that 20 -pack smokers would be less likely to quit smoking or switch brands if the price increased. ${ }^{23}$ For non-value brands, small packages were used to reduce prices without a discount that could 'denigrate the brand image'. ${ }^{78} 116183$

Large packages offering a value were similarly used as competitive tools to maintain and expand companies' market share through effects on brand-switching. For instance, a mall intercept study and group interviews found high interest in a 25 -pack of cigarettes as an 'economical option' that 'should be cheaper per unit'. ${ }^{133}$ In some cases, documents described the potential effects of large-package value offerings on a country's overall smoking rate and sales volume. ${ }^{385062}$ Most notably, one cigarette company executive was asked about the effects of a new 25 -pack on US cigarette consumption. ${ }^{38} \mathrm{He}$ responded that cigarette prices had been rising, which 'can increase the quit rate and also decrease the consumption of cigarettes per day'. ${ }^{38}$ By providing five extra cigarettes per package, he predicted that the 25 -pack could 'address the quitting issue to a degree and also address the rate per day by offering this value'. ${ }^{38}$ Another document similarly stated that the 25 -pack could 'stabilise the industry volume decline' caused by cigarette price increases. ${ }^{50}$ This document compared the idea of a 25 -pack to prior innovations such as filtered, 'low tar' and $100 \mathrm{~mm}$ cigarettes, which were said to have reversed industry volume declines caused by consumer awareness of smoking's health effects and by cigarette tax increases. ${ }^{50}$ However, 25-pack value offerings ultimately captured little US market share, in part because they 'ran counter to smokers' stated objectives of wishing to cut down on smoking. ${ }^{42}$ In contrast, the introduction of a 25-pack in Australia met high consumer demand and sparked a price war as competitors reacted with 30-pack, 35-pack and 40-pack offerings. ${ }^{62}$

\section{Response to tax increases}

Companies introduced new package quantities in response to excise tax increases-both to offset effects on their sales volume and to capitalise on consumers' increased price consciousness and likelihood of switching brands. ${ }^{30} 3235385051535862789095102123125132134$ 184-186 In one case, a 15-cigarette pack was introduced because 'taxation had driven up the price... The 15's pack gave new smokers an opportunity to try Export for under two dollars'. ${ }^{78}$ In anticipation of increased cigarette excise taxes, one company evaluated a RYO product in two tin sizes as alternatives to manufactured cigarettes for price-sensitive smokers. ${ }^{184} 187$ The company introduced a $30 \mathrm{~g}$ product into a marketplace dominated by $50 \mathrm{~g}$ pouches expecting that 'growth will be generated by its attractive price point in a market characterised by increasing government taxes'. ${ }^{32}$ Other documents similarly described how package quantity changes had been used to increase cigarette brands' market share following excise tax increases $\left(\mathrm{eg},{ }^{134}\right.$ ) or to retain consumers at risk of switching to value brands $\left(\mathrm{eg},{ }^{185}\right)$.

\section{Matching current and desired consumption rates}

Companies considered large and small packages as appealing to consumers by matching high ${ }^{25} 31424583138-144 \quad 188-195$ or low $68728284-89108110111128137188194$ 196-201 daily use rates. In some cases, consumers' daily use rates were said to differ from standard package quantities. ${ }^{24} 3133190198$ 202-204 In other cases, consumers were said to prefer non-standard package quantities that matched their desired use rate. Some smokers believed that larger packs would encourage them to smoke more, which they

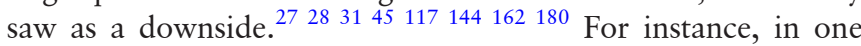
study, a top reason for disliking a carton of 20 packs (19 cigarettes each) was that it 'tempts you to smoke more' ${ }^{27}$ Conversely, smokers believed that smaller packs would help them ration their consumption and smoke less, potentially benefiting their health. ${ }^{22} 79838489128188189205-209$

Several documents stated that, because of effects on consumption rates, marketing small packages may decrease overall industry sales volumes. ${ }^{7194} 122208$ A focus group report concluded that introducing a 12-pack of cigarettes may hurt volume because any new sales from brand-switching 'would be more than offset by smokers who use the twelve pack to cut back'. ${ }^{208}$ Other documents similarly noted that 'widespread availability of 10's may result in slightly lower industry volume' because 'light smokers may consume less, given a convenient rationing unit'. ${ }^{7122}$ One company hired analysts to forecast the effects of banning sales of cigarette packs with fewer than 20 sticks in Puerto Rico: The document predicted that 'total market consumption will increase'. ${ }^{94}$ This was based on the company's observation that 'total market consumption increases with average pack size', which they theorised was because "small pack sizes are purchased in part, by 'Quitters' and 'Occasional' users, who are using the small pack sizes as a self-discipline to reduce consumption or quit smoking altogether". ${ }^{94}$ Another document also stated that market modelling had found a positive association between package quantity and sales volume. ${ }^{210}$ Relatedly, in Australia, large packs were credited with helping maintain industry sales volumes even as smoking prevalence fell. ${ }^{62}$

\section{Inaccurate premarket predictions}

In some cases, companies struggled to accurately predict the effects of package quantity changes on purchase behaviour. ${ }^{211-214}$ Research examined the effect of replacing 20-packs of cigarettes in vending machines with 12-packs, priced at per-cigarette parity. ${ }^{211}$ The 12 -packs led to a $47 \%$ decline in the brand's total share of cigarette sales in test-markets. ${ }^{211}$ Similarly, Skoal Long Cut suffered market losses after increasing its SLT can size from 1.0 to 1.2 ounces. ${ }^{212-214}$ The company's research suggested that the change would not affect consumer behaviour. ${ }^{212}$ A document explained the mistake by noting that the research had examined consumption but neglected purchase patterns: 'the study provided the cans to the consumers rather than requiring them 
to actually purchase the product', ${ }^{212}$ leading to 'a significant underestimation of what increasing the can size of Skoal by $20 \%$ would do'. ${ }^{214}$

\section{Demographic targeting}

Companies used consumer demographics such as age to understand the market for small packages. 2427110118199 For example, documents noted that young adult smokers tended to smoke less heavily than older ones. ${ }^{24}{ }^{27}$ Two documents contained data on smokers under age 18: German research collected data on heaviness of smoking and cigarette purchase behaviours among smokers in various age groups, including ages $16-24,{ }^{27}$ and US research examined intentions to buy a 10 -pack of KOOL cigarettes among Black smokers in various age groups, including ages 16-20. ${ }^{118}$ A Malaysia document noted that packs with fewer than 20 cigarettes 'addressed an important consumer segment' of 'younger consumers or starters with lower consumption needs'. ${ }^{199}$ Package quantity surveillance in Puerto Rico found that 14-packs were especially likely to be used by young adults 18-24 years old. ${ }^{215}$ Research on 'Project BUCK'-an effort to launch a cigarette 5-pack for $\$ 1.00$ in Canada-found that the concept had especially high appeal among smokers who were young (aged 18-34), 'starters' or 'switchers'. ${ }^{110}$ These groups' higher interest was thought to be driven by low sensitivity to per-stick prices and low daily consumption rates. ${ }^{110}$ The launch of a cigarette 10 -pack in Korea sought to generate trial among young adult smokers and 'starters'. ${ }^{72}$

Race and ethnicity were also examined. ${ }^{24216-219}$ One company considered introducing a 10-pack of 'Inner-City Black Targeted Brand' cigarettes because 'Blacks smoke fewer cigarettes per day and have less money' ${ }^{216}$ and because 'this smoker group is cost conscious, but rarely uses coupons or buys generic products'. ${ }^{217}$ A Black Smoker Study and a Brand Switcher study assessed whether Black smokers would buy KOOL 10-packs. ${ }^{218}$ Test-marketing of a Newport 10-pack found that sales were strongest in 'economically depressed areas' regardless of racial make-up. ${ }^{219}$

\section{Novelty}

Smokers viewed small packages as unique. 248183109198208220221 In focus groups, a cigarette 12-pack was seen as 'cute/a novelty' and 'something which sparked enough curiosity to stimulate a trial'. ${ }^{208}$ A subsequent market test found that the 12-pack could be used as a promotional device for several months per year: 'By doing this on a sporadic basis the novelty (the second most mentioned reason for buying) would not wear off'. ${ }^{222}$ The imagery associated with small packages was not always appealing 223 : Focus group research on cigarette 10-packs and 14-packs suggested that 'modifications would need to be made to the package to mitigate both 'feminine-looking' and/or 'sample size' feelings'. 224

\section{Ease of carrying or concealing}

Smaller packages were sometimes appealing because they made products easier to carry. ${ }^{30} 83-858889128137189193224-226$ A RYO pouch that was $30 \%$ smaller than others on the market was seen as 'a convenient size for social occasions'. ${ }^{30}$ Qualitative research in Paraguay found that 10-packs of cigarettes were 'easier to carry around"225; focus group participants stated that "“youngsters' (ages 10-13) like the '10's' pack very much because, since they 'aren't supposed to be smoking', they are 'easier to hide"'.225 Other qualitative research suggested this was also a reason for buying single cigarettes: 'students claimed they preferred cigarettes in loose form, as they smoked on the sly'. ${ }^{207}$

\section{Perceived freshness}

Smaller packages may have a consumer benefit in terms of perceived or actual freshness. $2289110136184187188193197206227-229$ This applied to consumers who expected to finish the product in a shorter period of time.

\section{Free sample packages}

Small cigarette packs were used as free samples for three reasons. ${ }^{230-236}$ State tax laws created logistical and cost advantages to giving away free packs that were small rather than large. ${ }^{231-234}$ Marketers expected giveaways of small rather than standard packs to be less threatening to retailers ${ }^{231}$ and harder for retailers to misappropriate (ie, sell rather than give away). ${ }^{231} 235$ Finally, small packages were cheaper to give away. Companies studied the profitability of their sampling programmes in terms of generating competitive trial and conversion (ie, use by smokers of competitor brands), estimating the conversion rate required to offset sampling costs within a given period of time. ${ }^{230235237}$ A promotion test comparing cigarette 10-packs and 20-packs as free samples concluded that the 20-pack led more smokers to purchase the brand in the next week but did not lead to a significantly higher conversion rate 6 weeks later. ${ }^{230}$

\section{DISCUSSION}

Previously secret industry documents described the consumer appeal of small and large packages. Large packages were more economical (per-unit), matched the consumption rates of longterm, heavy users, and were targeted at 'smart shoppers' and value brand users. Small packages were more affordable in terms of immediate cash outlay (overall price); matched the consumption rates of newer and lighter users and the desired consumption rates of others; attracted interest through novelty, convenience and perceived freshness; and were targeted at people with low income, young people, minorities and premium brand users. Targeting package quantities using brand, psychographic, lifestyle and demographic characteristics led companies to develop highly differentiated product portfolios (cf, $238{ }^{239}$ ). Even so, companies' premarket predictions about product uptake were sometimes highly inaccurate, with package quantity changes sometimes leading to large sales reductions.

As suggested previously, ${ }^{15} 16$ companies used novel package quantities to lower the price, either per-package or per-unit. Often, companies did this in response to excise tax increases. The stated goal of introducing new package quantities was to increase and defend brands' market share through effects on brand-switching — and, at times, quitting — among increasingly price-conscious consumers. Package quantity changes aimed at enhancing affordability were sometimes targeted at people with low income, young people and minorities, which may harm public health if it discourages quitting (cf, ${ }^{240-242}$ ). Prior research shows the importance of price in tobacco use, including among youth, ${ }^{240} 241243-248$ and highlights industry efforts to promote value-for-money. ${ }^{249}$

We did not find documents in which companies explicitly discussed the introduction of small packages as a way to encourage trial by non-users, or by youth. Documents suggested that companies strove to motivate brand-switching among users of competitor products and to react to competitive threats and changing consumer preferences that could erode market share or sales volume. No documents specifically described targeting non-users of products, although some referred to 'starters' and 'new users'. A prior review of packaging-related industry documents also found none describing the use of 'kiddie packs' to 
target minors. ${ }^{17}$ However, in another prior review, some documents appeared to use 'young adult' as a catch-all term for youth and young adults $\left({ }^{15}, \mathrm{pp} . \mathrm{i} 7-\mathrm{i} 10\right)$, and so we cannot rule out the possibility that 'young adults' in some of our documents included youth. Also, we cannot rule out that companies' marketing decisions would have the effect of encouraging trial among these populations. While documents did not explicitly discuss youth, they suggest several explanations for prior findings that youth prefer small packages. ${ }^{111}$ These include the traditional explanations of low price and ease of concealment ${ }^{2-7} 10$ as well as the notion that younger and newer users may simply prefer small packages because of the fit with their lower consumption rate.

Industry documents suggested that some current smokers preferred small cigarette packs as a tool to try to quit, cut down or maintain a desired consumption level. This accords with a prior study finding that many consumers-particularly those who see themselves as impulsive-prefer to purchase 'vices' in small quantities in order to try to constrain consumption. ${ }^{250}$ Research on US smokers' theoretical willingness-to-pay for 10-packs also suggests a desire to ration consumption. ${ }^{251}$ However, it is also possible that the availability of small packs would tempt people to make purchases that they would not have made if only larger packs were available, as small packages may 'fly under the radar' of people's self-control efforts. ${ }^{252}$ The role that these processes (consumption rationing, 'flying under the radar') may play in the purchase of small packages of tobacco products remains a topic for future research.

\section{Limitations}

This was a non-exhaustive search of the TTID. We reviewed and described all relevant documents we found, but we limited our search to 1980 or later and reviewed a small number of documents (216). The documents may not be representative of other TTID documents describing package quantity. Different companies may use different terminology, which could influence the documents we retrieved. Moreover, document authors may have self-censored their language to obscure particular marketing objectives as a matter of company policy or to avoid legal liabilities $\left({ }^{15}\right.$, pp. i7-i10). All documents in this review concerned cigarettes, RYO, SLT and 'smokeless cigarettes'. Most of the documents were old, with almost all from the 1980s and 1990s. Finally, we could not assess the veracity of research findings and many of the market predictions made in the documents.

\section{What this paper adds}

Little published research has evaluated the effects of marketing small or large packages on tobacco appeal, purchase or use.

- We reviewed previously secret industry documents to understand companies' rationales for changing or introducing new package quantities, as explained in companies' internal records, such as marketing plans and research documents.

- Package quantity changes were highly targeted by brand and consumer characteristics. Small and large packages were primarily marketed to reduce the per-package and per-unit prices of products, respectively, and to match consumers' actual or desired consumption rates.

- Documents described package quantity changes as a tool for increasing and defending a brand's market share through effects on brand-switching, but such changes also had potential implications for quitting behaviour.

\section{Conclusions}

Tobacco companies tailored package quantities to specific brands, consumer segments and markets, seeking to meet a complicated mix of preferences among current users. Documents also discussed starters, new users and younger users as potential target markets for small package quantities, primarily based on these individuals' lower consumption rates and lower sensitivity to per-unit (vs per-package) prices. As an industry document review, our analysis should be viewed tentatively and not as the conclusive word on any aspect of tobacco package quantity. Given this, we encourage continued scientific investigation of the role that package quantity may play in purchase and consumption behaviour among current users and non-users of tobacco products.

Contributors All three authors contributed by conceptualising the project; searching for, reviewing and summarising documents; and writing and revising the report.

Funding This work was not grant-supported but was funded via internal FDA resources.

Disclaimer This publication represents the views of the authors and does not represent FDA/CTP position or policy.

Competing interests None declared.

Patient consent Not required.

Provenance and peer review Not commissioned; externally peer reviewed.

(C) Article author(s) (or their employer(s) unless otherwise stated in the text of the article) 2019. All rights reserved. No commercial use is permitted unless otherwise expressly granted.

\section{REFERENCES}

1 Nguyen HV, Grootendorst P. Intended and unintended effects of restrictions on the sale of cigarillos to youth: evidence from Canada. Tob Control 2015;24:382-8.

2 Li W, Gouveia T, Sbarra C, et al. Has Boston's 2011 cigar packaging and pricing regulation reduced availability of single-flavoured cigars popular with youth? Tob Control 2017;26:135-40

3 NYC Department of Health and Mental Hygiene. New laws governing cigar sales in New York City tobacco retail stores: what you need to know. New York, United States: NYC Department of Health and Mental Hygiene.

4 Liber AC, Ross H, Omar M, et al. The impact of the Malaysian minimum cigarette price law: findings from the ITC Malaysia Survey. Tob Control 2015;24(Suppl 3):iii83-iii7.

5 U.S. Department of Health and Human Services. Reducing tobacco use: a report of the Surgeon General. Atlanta, Georgia, 2000.

6 World Health Organization. The WHO framework convention on tobacco control: an overview. $2015 \mathrm{http} / / /$ www.who.int/fctc/WHO_FCTC_summary_January2015_EN. pdf?ua $=1$.

7 Sherman B. For sake of children, Congress must ban 'kiddie packs': Los Angeles Times, 1998.

8 Chapman S. Australia: British American Tobacco "addresses" youth smoking. Tobacco Control 2007;16:2-3.

9 Daynard RA, Parmet W, Kelder G, et al. Implications for tobacco control of the multistate tobacco settlement. Am J Public Health 2001;91:1967-71.

10 Wilson DH, Wakefield MA, Esterman A, et al. 15's: they fit in everywhere-especially the school bag: a survey of purchases of packets of 15 cigarettes by 14 and 15 year olds in South Australia. Community Health Stud 1987;11(1 Suppl):16s-20.

11 Ireland Office of Tobacco Control. Children, youth, and tobacco: behavior, perceptions and public attitudes. Naas, Ireland: Office of Tobacco Control, 2006.

12 Hollands GJ, Shemilt I, Marteau TM, et al. Portion, package or tableware size for changing selection and consumption of food, alcohol and tobacco. Cochrane Database Syst Rev 2015:9:1-387.

13 Hurt RD, Robertson CR. Prying open the door to the tobacco industry's secrets about nicotine: the Minnesota Tobacco Trial. JAMA 1998:280:1173-81.

14 Industry Documents Library. Truth tobacco industry documents. https://www.industry documentslibrary.ucsf.edu/tobacco/.

15 Cummings KM, Morley CP, Horan JK, et al. Marketing to America's youth: evidence from corporate documents. Tob Control 2002;11(Suppl 1):15-17.

16 Kotnowski K, Hammond D. The impact of cigarette pack shape, size and opening: evidence from tobacco company documents. Addiction 2013;108:1658-68.

17 Difranza JR, Clark DM, Pollay RW. Cigarette package design: opportunities for disease prevention. Tob Induc Dis 2002;1:97-109. 
18 Anderson SJ, McCandless PM, Klausner K, et al. Tobacco documents research methodology. Tob Control 2011;20(Suppl 2):ii8-ii11.

19 Anderson SJ. Marketing of menthol cigarettes and consumer perceptions: a review of tobacco industry documents. Tob Control 2011;20(Suppl 2):ii20-ii8.

20 Rees VW, Kreslake JM, O'Connor RJ, et al. Methods used in internal industry clinical trials to assess tobacco risk reduction. Cancer Epidemiol Biomarkers Prev 2009;18:3196-208.

21 Lempert LK, Glantz S. Packaging colour research by tobacco companies: the pack as a product characteristic. Tob Control 2017;26:307-15.

22 Research S. 1994 (19940000) share trend tables (averages of May \& November 1994 (19940000)). 1995 https://industrydocuments.library.ucsf.edu/tobacco/docs/ znpy0013.

23 Intl R, Marketing P. 1993 (19930000) Consumer research summaries. year-end report. 1993 https://industrydocuments.library.ucsf.edu/tobacco/docs/gkpy0013.

24 PROGRAM. Package size configurations. 1989 https://industrydocuments.library.ucsf. edu/tobacco/docs/qskf0059.

25 Ml G, G M, Intl R. Consumer research report. 1993 (19930000) islandwide tracking study. $1993 \mathrm{https://www.industrydocumentslibrary.ucsf.edu/tobacco/docs/}$ rtpy0013.

26 Intl N. Cigarette pricing and strategic brand positioning study in japan management presentation presented: Hong Kong—8504001985.https://industrydocuments. library.ucsf.edu/tobacco/docs/mqxw0116

27 Intl N. Cigarette market structure and brand leverage study management presentation. $1985 \mathrm{https}$ ://industrydocuments.library.ucsf.edu/tobacco/docs/ kzlc0118

28 Research CB. Pack count exploratory study 23's 25's five pack six pack. 1983 https:// industrydocuments.library.ucsf.edu/tobacco/docs/fgbl0103

29 Industry documents library. The Cigarette Segmentation Study volume V — summary manual. 1990https://industrydocuments.library.ucsf.edu/tobacco/docs/mnfc0202

30 Morris P, Inc P, Webb W. New product introduction Marlboro RYO. 1994 https:// industrydocuments.library.ucsf.edu/tobacco/docs/grvb0218

31 Limited ECARP. Evaluation of opportunities in the value segment of the cigarette market. 1990 https://industrydocuments.library.ucsf.edu/tobacco/docs/sfmd0202

32 Industry documents library. CPC submission 951100 Marlboro (RYO) pouch tobacco 30 \& 50 grams. 1995 https://industrydocuments. library.ucsf.edu/tobacco/docs/ ktlp0217

33 Pm PM. New Marlboro 25's leader's guide. 1984 https://industrydocuments.library. ucsf.edu/tobacco/docs/fslw0049

34 WD, Limited HW. Conversion model study—summary report. 1995https:// industrydocuments.library.ucsf.edu/tobacco/docs/shhd0204

35 Industry documents library. Analysis of price and value for money in the cigarette market. 1984 https://industrydocuments.library.ucsf.edu/tobacco/docs/nxmm0135

36 Industry documents library. Brown \& Williamson 840000 direct marketing plan. 1984 https://www.industrydocumentslibrary.ucsf.edu/tobacco/docs/fqwm0135

37 Mellman A. Strategic Plan. 1983 https://www.industrydocumentslibrary.ucsf.edu/ tobacco/docs/nzcd0139

38 Industry documents library. Maxwell seminar-question/answers. 1983https://www industrydocumentslibrary.ucsf.edu/tobacco/docs/rpcv0101

39 Industry documents library. PM USA Corporate Affairs five-year plan. 1985 https:// www.industrydocumentslibrary.ucsf.edu/tobacco/docs/yilj0111

40 M A, Kush A. Facsimile cover sheet pack size legislation. 1998 https://www.industry documentslibrary.ucsf.edu/tobacco/docs/ttmp0062

41 Industry documents library. B\&W plan follow up with P Sheehy-domestic marketing. 1998https://www.industrydocumentslibrary.ucsf.edu/tobacco/docs/ xfhk0141

42 Industry documents library. Brown \& Williamson analysis of industry pricing dynamics and recommended strategies. 1997 https://www.industrydocumentslibrary. ucsf.edu/tobacco/docs/njpm0190

43 Pm PM, Udow A. Increased pack size1. 1983 https://www.industrydocumentslibrary. ucsf.edu/tobacco/docs/rzdy0038

44 Industry documents library. Joint Research on Blue Mould in Puerto Rico. 1984 https://www.industrydocumentslibrary.ucsf.edu/tobacco/docs/jjnb0002

45 Industry documents library. Limiting factors in changing cigarette pack sizes. 1985 https://www.industrydocumentslibrary.ucsf.edu/tobacco/docs/hxwv0196

46 Rj R. Parity pricing vs. pack size. 1986 https://industrydocuments.library.ucsf.edu/ tobacco/docs/hzhx0079

47 Industry documents library. Rationalisation of pack sizes. $1992 \mathrm{https}: / / w w w . i n d u s t r y$ documentslibrary.ucsf.edu/tobacco/docs/grxv0194

48 Aiken S. Limited B-ATC. Rationalisation of pack sizes. 1993 https://www.industry documentslibrary.ucsf.edu/tobacco/docs/tyxk0196

49 Pm PM, Murray R, A P. New product introduction Raffles 100'S IN 10'S pack. 1986 https://industrydocuments.library.ucsf.edu/tobacco/docs/qgdj0111

50 INTERNATIONAL. 4/61983 December 31. https://industrydocuments. library.ucsf.edu/ tobacco/docs/qjkg0016

51 RJRMI. Market analysis for 15's format. 1988 https://www.industrydocumentslibrary. ucsf.edu/tobacco/docs/ssyv0223

52 Industry documents library. 840000 Viceroy strategic plan. 1984 https://www.indu strydocumentslibrary.ucsf.edu/tobacco/docs/jqmf0134
53 EEC EEC. PROJECT SILVER. 1993 https://www.industrydocumentslibrary.ucsf.edu/ tobacco/docs/nrfj0115

54 PUERTO RICO/SBU. Market overview. 1994 https://www.industrydocumentslibrary. ucsf.edu/tobacco/docs/zjgv0187

55 Industry documents library. Price war Belgium action plan. $1994 \mathrm{https}: / /$ www.indu strydocumentslibrary.ucsf.edu/tobacco/docs/lybj0115

56 Industry documents library. BWT 870000 strategic planning meeting background information. 1986 https://www.industrydocumentslibrary.ucsf.edu/tobacco/docs/ xxpw0146

57 Industry documents library. Truth tobocco industry documents. 1986 https://www. industrydocumentslibrary.ucsf.edu/tobacco/docs/rhcj0130

58 Fennell P. Rothmans of Pall Mall Limited - Operation Fireball update-board of directors meeting. 1985https://www.industrydocumentslibrary.ucsf.edu/tobacco/ docs/qglv0223

59 Levy JM. Limited B-ATC. Pall Mall brand guidelines. 1999 https://www.industrydocu mentslibrary.ucsf.edu/tobacco/docs/glxy0202

60 Industry documents library. Jr-Puerto Rico 1990-1992 (900000-920000) strategic plan. 1992https://www.industrydocumentslibrary.ucsf.edu/tobacco/docs/qzvp0078

61 Research M. Marketing plans 1992. 1991 https://www.industrydocumentslibrary. ucsf.edu/tobacco/docs/jxmv0223

62 Philip Morris Records. Value segment synopsis — the Australian market, 1990.

63 Industry documents library. Americas strategic plan review 1994-1998 agenda. 1994https://www.industrydocumentslibrary.ucsf.edu/tobacco/docs/rmyv0223

64 Australia W. General manager's monthly review Australia. 1996 https://www.indu strydocumentslibrary.ucsf.edu/tobacco/docs/mqgb0209

65 Perceptions M. Exploring consumers reactions to Camel Wides a qualitative research study. 1992 https://www.industrydocumentslibrary.ucsf.edu/tobacco/docs/lhwy0130

66 Industry Documents Library. Puerto Rico 1991 (910000) operating plan. 1991 https://www.industrydocumentslibrary.ucsf.edu/tobacco/docs/zjgw0185

67 PMI PMI. Philip Morris Asia/Pacific three year plan 920000-9400001994.https:// www.industrydocumentslibrary.ucsf.edu/tobacco/docs/fynb0110

68 Industry Documents Library. Business review 92/93 (RBH-1136) (suite). 1992 https:// www.industrydocumentslibrary.ucsf.edu/tobacco/docs/ztkx0149

69 PERCEPTIONS M. Truth of tobacco industry documents. 1992 https://www.industry documentslibrary.ucsf.edu/tobacco/docs/mnyv0152

70 Industry Documents Library. 940000 action points_France. 1994 https://www.indu strydocumentslibrary.ucsf.edu/tobacco/docs/qnbj0115.

71 Industry Documents Library. $840000 \mathrm{KOOL}$ operational plan. $1984 \mathrm{https}: / / w w w . i n d u$ strydocumentslibrary.ucsf.edu/tobacco/docs/hqyv0133

72 PM PM. Marlboro medium 10's_-Korea cpc submission for 941100 meeting. 1994https://www.industrydocumentslibrary.ucsf.edu/tobacco/docs/pkwk0053

73 Industry Documents Library. Truth tobacco industry documents. 1984 https://www. industrydocumentslibrary.ucsf.edu/tobacco/docs/mscw0134

74 RJRMI. 1989 operating plan presentation. 1988 https://www.industrydocument slibrary.ucsf.edu/tobacco/docs/tsyv0223

75 Industry Documents Library. P-50: 1991 Marketing Plans. 1991 https://www.industry documentslibrary.ucsf.edu/tobacco/docs/zzfb0223

76 Puerto R. 1992 (19920000) OPERATION PLAN. CONTENTS. 1992 https://www.indu strydocumentslibrary.ucsf.edu/tobacco/docs/rpyy0013

77 Pm PM, Murphy M. Variable pack sizes. 1983 https://www.industrydocumentslibrary. ucsf.edu/tobacco/docs/sgdk0129

78 Industry Documents Library. Mlami marketing conference may 14-16, 1990 (900514) (900516). "Export a" the renaissance of Canada's best selling brand. 1990https://industrydocuments. library.ucsf.edu/tobacco/docs/jnlv0185

79 News G, Record. Cigarette mini-pack gets mixed reaction. 1983 https:// industrydocuments.library.ucsf.edu/tobacco/docs/sskk0004

80 Gordon DL. New product planning / 393. 1987 https://www.industrydocument slibrary.ucsf.edu/tobacco/docs/pxck0037

81 Perceptions M, Wolf M. Special 10's qualitative research. 1993 https://www.industry documentslibrary.ucsf.edu/tobacco/docs/frbl0122

82 ATCO. Special 10 s1994. https://industrydocuments.library.ucsf.edu/tobacco/docs/ tthx0136

83 Research KM. Alternative pack concepts for Kim, a new female-oriented cigarette-a unifocus study. 1985https://www.industrydocumentslibrary.ucsf.edu/ tobacco/docs/qxkd0132

84 Carter S. Summary analysis of eight focus discussion groups on cigarette 12 pack for Lorillard (861100). 1986 https://www.industrydocumentslibrary.ucsf.edu/tobacco/ docs/xnll0115

85 Pmi PMI. 10S pack launches PMI international study. 1993 https://www.industry documentslibrary.ucsf.edu/tobacco/docs/nhkl0113.

86 Pm PM, Lopez A. Virginia slims 10's and new advertising-qualitative assessment (final report). 1992https://www.industrydocumentslibrary.ucsf.edu/tobacco/docs/ nrvb0112

87 Industry Documents Library. Exhibit B summary discussion. I. nature of the proposal. 1994 https://www.industrydocumentslibrary.ucsf.edu/tobacco/docs/qlcd0185

88 ASSOC PAW. Management summary of findings on new menthol brand packaging, premiums and promotional concepts. $1990 \mathrm{https} / / /$ www.industrydocumentslibrary. ucsf.edu/tobacco/docs/kfhg0059 
89 Intl R, Ml G, Le M. Islandwide tracking study may 1996 (19960500). consumer research report. mpr no. pr003/96. islandwide tracking study final report. 1996 https://www.industrydocumentslibrary.ucsf.edu/tobacco/docs/qjwv0187

90 Pmi PMI. 960000 new product launches and line extensions. 1996 https://www.indu strydocumentslibrary.ucsf.edu/tobacco/docs/sqkf0069

91 Industry Documents Library. 940000 action points-Benelux. 1994https://www.indu strydocumentslibrary.ucsf.edu/tobacco/docs/pnbj0115

92 Pmai P. Research overview of Singapore Malaysia Thailand. 1991 https://www.indu strydocumentslibrary.ucsf.edu/tobacco/docs/jjld0110

93 Bravo MD, Morris P, Pmusa PMU, et al. Philip Morris completed projects 200000002000. https://www.industrydocumentslibrary.ucsf.edu/tobacco/docs/ krvl0162

94 Industry Documents Library. FDA Regulations 10's \& 14's pack sizes—Puerto Rico. 1997https://www.industrydocumentslibrary.ucsf.edu/tobacco/docs/sgff0102

95 At S. 12-pack sales test marketing strategy plan. 1982https://www.industrydocu mentslibrary.ucsf.edu/tobacco/docs/sthv0019

96 Industry Documents Library. 1998 to 2000 strategic plan Canada. 1997 https:// www.industrydocumentslibrary.ucsf.edu/tobacco/docs/rlhb0223

97 Pmi PMI. Five year plan 940000-980000. 1994https://www.industrydocument slibrary.ucsf.edu/tobacco/docs/lpjy0002

98 Pmi PMI. Latin America region three year plan 880000-900000. 1988https://www. industrydocumentslibrary.ucsf.edu/tobacco/docs/fjpw0143

99 Riehl T. Domestic product development committee meeting report \#1571983. https://www.industrydocumentslibrary.ucsf.edu/tobacco/docs/kgnw0134.

100 Ideanet RJR. The place for new product \& packaging ideas. $2003 \mathrm{https}: / /$ www.indu strydocumentslibrary.ucsf.edu/tobacco/docs/klpx0224.

101 B D. An audit of consumer research on camel brand imagery and consumer attitudes in Western Eastern Europe. 1995 https://www.industrydocumentslibrary.ucsf.edu/ tobacco/docs/kywd0089

102 Industry Documents Library. Key strategic priorities. 1990https://www.industrydocu mentslibrary.ucsf.edu/tobacco/docs/nrbv0111

103 Ml G, Rjr MG. Consumer research report. Value brands group sessions. 1994 https:// www.industrydocumentslibrary.ucsf.edu/tobacco/docs/pryy0013

104 Jd F, Intl R. 8. PR1986 014. Consumer research report. Puerto Rico 1986 (19860000) islandwide tracking study. $1987 \mathrm{https}: / /$ www.industrydocumentslibrary.ucsf.edu/ tobacco/docs/hzpy0013

105 Intl G. The market for cigarettes in Puerto Rico summary of key findings. 1992 https://www.industrydocumentslibrary.ucsf.edu/tobacco/docs/tjjv0110

106 Jy M. Dept MD. Female smokers. 1984 https://www.industrydocumentslibrary.ucsf edu/tobacco/docs/jgjg0096

107 Pm PM, Ziegenhagen M. Minutes of the NPC meeting held on wednesday 841003 at 17: 00 at the Beau-Rivage Hotel. 1984 https://www.industrydocumentslibrary. ucsf.edu/tobacco/docs/ggpm0114

108 Industry Documents Library. France Philip Morris Super Lights 10's. 1994 https:// www.industrydocumentslibrary.ucsf.edu/tobacco/docs/rkwk0053

109 Audet-Lapointe C. Switching analysis. 1991 https://www.industrydocumentslibrary. ucsf.edu/tobacco/docs/gpbb0223

110 Industry Documents Library. Project buck. 1989 https://www.industrydocument slibrary.ucsf.edu/tobacco/docs/tfdb0223

111 Industry Documents Library. Project delta review. 1988 https://www.industrydocu mentslibrary.ucsf.edu/tobacco/docs/nsnn0119

112 Industry Documents Library. Malaysia 3yp plan 940000 to 960000.1994 https:// www.industrydocumentslibrary.ucsf.edu/tobacco/docs/ntbd0110

113 Industry Documents Library. Malaysia—ob 940000. 1994https://www.industrydocu mentslibrary.ucsf.edu/tobacco/docs/mtbd0110

114 BATCo. Wills New Zealand Corporate Plan 1993-97 No7 BAT. 1992https://www. industrydocumentslibrary.ucsf.edu/tobacco/docs/nxnp0199

115 Industry Documents Library. 12-PACK Sales test. Agenda. 1982 https://www.industry documentslibrary.ucsf.edu/tobacco/docs/rygw0003

116 Industry Documents Library. New product strategy. 1984 https://www.industrydocu mentslibrary.ucsf.edu/tobacco/docs/hwf0134

117 Research SBD. An exploratory study_ pricing: price-conscious vs. non-priceconscious smokers. 1983https://www.industrydocumentslibrary.ucsf.edu/tobacco/ docs/mpcx0063

118 Industry Documents Library. Black smoker study 840000. 1984 https://www.industry documentslibrary.ucsf.edu/tobacco/docs/qykm0135

119 Industry Documents Library. Review of background information. 1985 https://www. industrydocumentslibrary.ucsf.edu/tobacco/docs/mjlm0135

120 Gravely L. Subject: black smoker likelihood of buying ten (10) cigarette package size of Kool (1984-265Y). 1985 https://www.industrydocumentslibrary.ucsf.edu/tobacco/ docs $/ \mathrm{kmlk0045}$

121 Industry Documents Library. Black market overview. 1982 https://www.industrydocu mentslibrary.ucsf.edu/tobacco/docs/gtky0143

122 Industry Documents Library. Marketing plans. 1993 https://www.industrydocument slibrary.ucsf.edu/tobacco/docs/yghg0133

123 Incorporated R-M. 1991-1992 Business overview cigarettes (RJR-0080). 1992https://www.industrydocumentslibrary.ucsf.edu/tobacco/docs/xklx0149
124 Industry Documents Library. Regional business plan-Quebec. 1988https://www. industrydocumentslibrary.ucsf.edu/tobacco/docs//fpv0223

125 R E. 1991 priorities. 1991 https://www.industrydocumentslibrary.ucsf.edu/tobacco/ docs/lqvb0223

126 Roubicek H. Product 1990. 1989 https://www.industrydocumentslibrary.ucsf.edu/ tobacco/docs/fhjn0209

127 Naughton N. Test market selection for Viceroy trial pack test. 1983 https://www.indu strydocumentslibrary.ucsf.edu/tobacco/docs/ttlf0134

128 Industry Documents Library. Segmentation — phase I-focus group research — Ontario/Quebec. 1991https://www.industrydocumentslibrary.ucsf.edu/tobacco/docs/ jqcb0223

129 Intl R, Im B. Project W.I.T. research report \#3. 1994 https://www.industrydocument slibrary.ucsf.edu/tobacco/docs/rqpy0013

130 Intl R, Ht P. Marketing department weekly brief for week ending April 5, 1992 (19920405). 1992 https://www.industrydocumentslibrary.ucsf.edu/tobacco/docs/ mrwv0187

131 Industry Documents Library. 1996 (19960000) operating plan Puerto Rico. 1995 https://www.industrydocumentslibrary.ucsf.edu/tobacco/docs/hlkp0186

$132 \mathrm{HI} \mathrm{JR}$, Jr m JWJ, Ml O, et al. 12-pack retail sales research. 1982 https://www.industry documentslibrary.ucsf.edu/tobacco/docs/kznb0099

133 Johnston M. Subject: still more trends in cigarette smoking prevalence. 1983 https:// industrydocuments.library.ucsf.edu/tobacco/docs/sknj0045

134 Intl R, Ge H. Marketing responses to excise tax increases. Reports related to the fet increase. International tax analysis. $1982 \mathrm{https}$ ://www.industrydocumentslibrary.ucsf. edu/tobacco/docs/rqhj0095

135 Australia. Overview. 2007 https://industrydocuments.library.ucsf.edu/tobacco/docs kykf0222

136 Research D, Je f LD. Focus groups to evaluate concepts. New brand task force. Project infinity. $1991 \mathrm{https} / / /$ industrydocuments. library.ucsf.edu/tobacco/docs/ gtxn0046

137 Industry Documents Library. Alternative pack concepts for "Kim," a new femaleoriented cigarette a unifocus study. 1985 https://www.industrydocumentslibrary. ucsf.edu/tobacco/docs/pfdj0037

138 Pm PM. Five year plan 850000-890000. 1985https://www.industrydocument slibrary.ucsf.edu/tobacco/docs/psln0108

139 Pm PM, Jones J, Rowe C, et al. 830000 mall test of new cigarette product ideas. 1984 https://www.industrydocumentslibrary.ucsf.edu/tobacco/docs/gtyg0143

140 Jacks BW. Creative strategy. 1983 https://www.industrydocumentslibrary.ucsf.edu/ tobacco/docs/jlyy0143

141 Robinson W. Australian cigarette market. 1983 https://www.industrydocument slibrary.ucsf.edu/tobacco/docs/jkvb0133

142 Rj h RJR. New business research and development report. Project VB assessor qualitative exploratory topline perspective. 1983 https://www.industrydocument slibrary.ucsf.edu/tobacco/docs/zmkl0184

143 Strasser P. No Title 1983. https://www.industrydocumentslibrary.ucsf.edu/tobacco/ docs/ktcd0139

144 Pellett B. Alpha B 25-pack evaluation final report. 1983 https://www.industrydocu mentslibrary.ucsf.edu/tobacco/docs/ntcd0139

145 R-w B. Australian 25-Pack Market. 1983https://www.industrydocumentslibrary.ucsf. edu/tobacco/docs/syjv0143

146 Intl ES. The world cigarette market: the 920000 international survey volume III Asia Australasia \& The Far East Middle East \& Africa. 1992 https://www.industrydocu mentslibrary.ucsf.edu/tobacco/docs/qpxm0166

147 INTL MA, B A, G R, H M, N H. Philip Morris Holland B.V. some considerations and recommendations on merit. $1981 \mathrm{https} / / / \mathrm{www}$.industrydocumentslibrary.ucsf.edu/ tobacco/docs/ryyp0110

148 MVF I, UNK. Century 1984 (840000) annual marketing plan. 1983 https://www.indu strydocumentslibrary.ucsf.edu/tobacco/docs/kjfj0096

149 Morris P, Inc P, Buzzi A. New product introduction Longbeach Ultra Mild 25'S. 1990 https://www.industrydocumentslibrary.ucsf.edu/tobacco/docs/jpjj0033

150 Industry Documents Library. 1993/94 Business Review (RBH-1137) (Suite). 1994 https://www.industrydocumentslibrary.ucsf.edu/tobacco/docs/mzkx0149

151 Pmi PMI. The price/value category — a review. 1988https://www.industrydocument slibrary.ucsf.edu/tobacco/docs/sskg0036

152 Inc BMS. Package size evaluation study II. 1983 https://www.industrydocument slibrary.ucsf.edu/tobacco/docs/ytcd0139

153 RJR. Century 1984 (840000) annual marketing plan. 1984 https://www.industry documentslibrary.ucsf.edu/tobacco/docs/sncg0083

154 Industry Documents Library. VB national introduction plan. $1983 \mathrm{https}: / /$ www.indu strydocumentslibrary.ucsf.edu/tobacco/docs/hgnm0093

$155 \mathrm{Rj} \mathrm{H}$. New business research and development report. Project VB packaging evaluation (MDD \#83-42702). 1983 https://www.industrydocumentslibrary.ucsf.edu/ tobacco/docs/flmk0184

156 Pm PM. Philip Morris U.S.A. five year plan 860000-900000. 1986https://www.indu strydocumentslibrary.ucsf.edu/tobacco/docs/gpkn0108

157 Morris P, Pmi PMI, Bliley G, et al. New product introduction Mark Ten Special Light 100's. 1984 https://www.industrydocumentslibrary.ucsf.edu/tobacco/docs/ fqud0028 
158 Rj H. New business research and development report. Project VB packaging evaluation. 1983 https://www.industrydocumentslibrary.ucsf.edu/tobacco/docs/ Ighh0096

159 Industry Documents Library. Project III a new product opportunity to capitalize on the male smoker target potentiaL. 1984 https://www.industrydocumentslibrary.ucsf. edu/tobacco/docs/lscg0134

160 JT W J T. Wilson update 1983. https://www.industrydocumentslibrary.ucsf.edu/ tobacco/docs/lkph0096

161 Industry Documents Library. Project three meeting - 830715. 1983https://www.indu strydocumentslibrary.ucsf.edu/tobacco/docs/xkwg0134

162 C-j B. Beta 25 s Creative qualitative research — final report (MRD \#1985-205NP). 1986https://www.industrydocumentslibrary.ucsf.edu/tobacco/docs/smcx0141

163 Industry Documents Library. Australian 25's case history. 1983 https://www.industry documentslibrary.ucsf.edu/tobacco/docs/rnkk0023

164 Inc NI. Project ultra light phase I and II. Focus group summaries and recommended next steps. 1980 https://www.industrydocumentslibrary.ucsf.edu/tobacco/docs/ mqhm0136

165 Goldberg H. Downside for 930000. 1993 https://www.industrydocumentslibrary. ucsf.edu/tobacco/docs/rnxg0080

166 Industry Documents Library. Qualitative study of cigarette smokers reactions to the 25 concept report for Brown \& Williamson Tobacco Corp. 1983https://www.industry documentslibrary.ucsf.edu/tobacco/docs/xmpm0135

167 Industry Documents Library. RJR Nabisco Holdings Corp competitive analysis. 1993 https://www.industrydocumentslibrary.ucsf.edu/tobacco/docs/nzvy0025

168 Bowen-E L-CPM. Capri in-depth interviews. 1987 https://www.industrydocument slibrary.ucsf.edu/tobacco/docs/sjwl0132.

169 Industry Documents Library. Overview. 1983 https://www.industrydocumentslibrary. ucsf.edu/tobacco/docs/kzyl0184

170 Ks R. New business research and development report. Project VB introductory advertising recall test. 1983 https://www.industrydocumentslibrary.ucsf.edu/tobacco/ docs/nxjx0096

171 Morgan J. PMUSA PMU. Value segment synopsis — the Australian market. 1990https://www.industrydocumentslibrary.ucsf.edu/tobacco/docs/nfdj0046

172 Limited B-ATC. Pall Mall synthesis of the brand repositioning studies. $1996 \mathrm{https}: / /$ www.industrydocumentslibrary.ucsf.edu/tobacco/docs/hxdf0200

173 Lba LEO. Findings from the L\&M copy research—first round. 2000https://www.indu strydocumentslibrary.ucsf.edu/tobacco/docs/pmkm0177

$174 \mathrm{Br} \mathrm{M}$, Research B. Project PB value-added exploratory. 1981 https://www.industry documentslibrary.ucsf.edu/tobacco/docs/ntcc0102

175 Rjr GHL. VB presentation-RJRI board. 1983https://www.industrydocumentslibrary. ucsf.edu/tobacco/docs/kzfg0098

176 Me S, Rjr PS. Century post-introductory copy strategy. 1983 https://www.industry documentslibrary.ucsf.edu/tobacco/docs/pkyx0013

177 Worldwide LR. Snus mapping study. Assessing the snus category landscape to drive growth and competitive advantage. 2009 https://industrydocuments.library.ucsf.edu/ tobacco/docs/hrml0222

178 Limited IT. Listing (H-4) 1998.https://www.industrydocumentslibrary.ucsf.edu/ tobacco/docs/hgpv0223

179 Industry Documents Library. Puerto Rico intercompany data exchange. 1994 https:// www.industrydocumentslibrary.ucsf.edu/tobacco/docs/qqpy0013

180 Industry Documents Library. Consumers and the cigarette market in the $800000 \mathrm{~s}$ : a

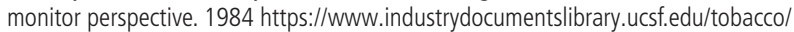
docs/mymb0136

181 RJR. Century filters and lights introduction. Miscellaneous. 1983 https://www.indu strydocumentslibrary.ucsf.edu/tobacco/docs/xxvw0083

182 Cunningham, Walsh. Project III; a new opportunity to capitalize on the male smoker target potential. 1984 https://www.industrydocumentslibrary.ucsf.edu/tobacco/docs/ yhhp0143

183 Stevens B. Europe company plan 1993 - 1997. 1992 https://industrydocuments. library.ucsf.edu/tobacco/docs/sfgc0199

184 Halpern M, Rao A. Royce in-depths 931103-931104. 1993https:// industrydocuments.library.ucsf.edu/tobacco/docs/rkwp0151

185 Rjr-Puerto R. 1996 (920000-960000) Strategic plan 1992. 1992https:// industrydocuments.library.ucsf.edu/tobacco/docs/rzvp0078

186 Lor L, Fauerbach K. Newport half-pack volume update. 1995 https://www.industry documentslibrary.ucsf.edu/tobacco/docs/glyn0065

187 Industry Documents Library. Market overview. 1995 https://industrydocuments. library.ucsf.edu/tobacco/docs/nfjp0072

188 Industry Documents Library. Package size evaluation study. 1983 https://www.indu strydocumentslibrary.ucsf.edu/tobacco/docs/mnlj0140

189 Sommers T. Final report: alternative packaging size evaluation. 1983 https://www. industrydocumentslibrary.ucsf.edu/tobacco/docs/frgg0134

190 Pm PM, Stirlen R. Marlboro 25'S 1984. https://www.industrydocumentslibrary.ucsf. edu/tobacco/docs/sjxy0038

191 Industry Documents Library. Marlboro 25's. 1984 https://www.industrydocument slibrary.ucsf.edu/tobacco/docs/fgyk0038

192 Industry Documents Library. 25 pack package size study. 1983 https://www.industry documentslibrary.ucsf.edu/tobacco/docs/hkcf0142
193 Research Q. Oona IV, qualitative research Calgary, July 1995 (RBH-4182). 1995 https://www.industrydocumentslibrary.ucsf.edu/tobacco/docs/mxyx0149

194 Factors A. Add-on questions by demo banners \& category banners 'menthol configuration/pack size concepts' 850300 cigarette brand switching study. 1985 https://www.industrydocumentslibrary.ucsf.edu/tobacco/docs/gyxh0113

195 Lightstone T. Summary report smoking buying habits study. 1990 https://www.indu strydocumentslibrary.ucsf.edu/tobacco/docs/rpyv0223

196 Morris P, Pmi PMI, Pickstock H, et al. New product introduction Longbeach Super Mild. 1999 https://www.industrydocumentslibrary.ucsf.edu/tobacco/docs/xhdk0218

197 Initiatives P. RJR Macdonald 1992 Marketing conference presentation report. 1992 https://www.industrydocumentslibrary.ucsf.edu/tobacco/docs/gyyv0223

198 Generation I. SEmi-rigid package study. A qualitative exploration of consumer reactions to a new type of packaging for cigarettes. $1986 \mathrm{https}: / /$ www.industrydocu mentslibrary.ucsf.edu/tobacco/docs/tgmb0086

199 Mms B, Vasudevan B. Lucky Strike minipack: a market overview and proposal for launch of a 14 stick pack. 1992 https://www.industrydocumentslibrary.ucsf.edu/ tobacco/docs/ylyn0193

200 Industry Documents Library. Agenda. 1986 https://www.industrydocumentslibrary. ucsf.edu/tobacco/docs/sthb0129

201 Gravely L. Summary of market research data for price/value task force (MRD 1985-72Y). 1985https://www.industrydocumentslibrary.ucsf.edu/tobacco/docs/ nzbg0134

202 RJR. Camel snus 2008. https://industrydocuments.library.ucsf.edu/tobacco/docs/ knwn0222

203 RJR. NGI steering committee 2008. https://industrydocuments.library.ucsf.edu/ tobacco/docs/kkkf0222

204 Limited B-ATC, Ashe S. Lucky Strike Twin Fives project. 1992 https:// industrydocuments.library.ucsf.edu/tobacco/docs/fhjy0194

205 Monaghan J. Curtis judge. 1988 https://industrydocuments. library.ucsf.edu/tobacco/ docs/zgcx0118

206 Assoc PAW. Management summary on reactions to new creative, packaging and

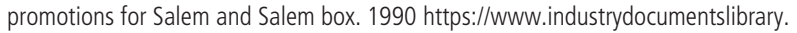
ucsf.edu/tobacco/docs/zzhg0059

207 Limited LMRB. Cigarettes: report on a qualitative research study on Gold Leaf. 1990 https://industrydocuments.library.ucsf.edu/tobacco/docs/lkdg0202

208 Cox AR. Twelve pack focus groups. 1983 https://industrydocuments.library.ucsf.edu/ tobacco/docs/styp0094

209 Industry Documents Library. Lynn Kozlowski 1988. https://industrydocuments.library. ucsf.edu/tobacco/docs/flmv0170

210 Intl R, En p CB, Ht P, et al. Reynolds Tobacco International, Inc. marketing research proposal. Pack size dynamics - qualitative test. 1992https://www.industrydocument slibrary.ucsf.edu/tobacco/docs/tthw0004

211 He O. Parity pricing versus pack size. 1986 https://industrydocuments.library.ucsf. edu/tobacco/docs/sfdx0079

212 BOSTON CSF, CALL F, FINANCIAL T. Lowering 2000 (20000000) AND 2001 (20010000) earnings estimates. 2000 https://industrydocuments.library.ucsf.edu/ tobacco/docs/kxdw0024

213 R S, Fenner MLP, R.J S. Reynolds: enjoying higher interest rates. 2000 https:// industrydocuments.library.ucsf.edu/tobacco/docs/lmck0011

214 DJ A, S M, K D, et al. Tobacco: December litigation event time line. 2000 https:// industrydocuments.library.ucsf.edu/tobacco/docs/gqhk0011

215 Industry Documents Library. 1993 (19930000) operating plan presentation. Toronto, Canada. September 16-18, 1992 (19920916-19920918). 1993https://www.indu strydocumentslibrary.ucsf.edu/tobacco/docs/pxpy0013

216 Industry Documents Library. 1990 Ideas. 1989 https://industrydocuments.library.ucsf edu/tobacco/docs/hrcv0095

217 GR D, LBB I, RJR. R\&D weekly highlights. 1989 https://industrydocuments.library. ucsf.edu/tobacco/docs/hmgb0090

218 Gravely L. Lack smokerl "likelihood of buyingl " ten (10) cigarette package size KOOL; black smoker "likelihood of buying" ten (10) cigarette package size KOOL. 1985https://www.industrydocumentslibrary.ucsf.edu/tobacco/docs/yfcg0134

219 Pm PM, Potter D. Newport half-pack. 1992 https://www.industrydocumentslibrary. ucsf.edu/tobacco/docs/lfpb0084

220 Shewchuk A. Re: status report on craven a light and recommendations for future plans. 1986 https://industrydocuments.library.ucsf.edu/tobacco/docs/fxdb0223

221 Rd S. 12-pack vending test. 1983 https://www.industrydocumentslibrary.ucsf.edu/ tobacco/docs/lznb0099

222 Cox AR. Twelve pack consumer research (MDD \#82-11111). $1983 \mathrm{https://}$ industrydocuments.library.ucsf.edu/tobacco/docs/ztyp0094

223 Perceptions M. Exploring consumer response to Marlboro new carton size concepts a qualitative research study. 1991 https://www.industrydocumentslibrary.ucsf.edu/ tobacco/docs/mhwy0130

224 RESEARCH EQ. A qualitative analysis. Camel new product concept screening exploration. 1991 https://industrydocuments.library.ucsf.edu/tobacco/docs/fnvp0081

225 Bwit CR. Kent qualitative research—Paraguay 1981.https://industrydocuments. library.ucsf.edu/tobacco/docs/ftcf0146

226 Pm PM, Stern D. Cartier in-store test 1990. https://www.industrydocumentslibrary. ucsf.edu/tobacco/docs/pkkk0129 
227 Pm PM, Shore C. 10'S pack test market-Hartford, CT. Virginia Slims half-pack test market (region 3) elements memo-revision. 1992https://industrydocuments.library. ucsf.edu/tobacco/docs/ykwp0126

228 Industry Documents Library. Cigarette packaging opportunities. 2000 https://www. industrydocumentslibrary.ucsf.edu/tobacco/docs/xInw0224

229 CALLE. Philip Morris, Inc. new menthol cigarette assay. 1986 https://www.industry documentslibrary.ucsf.edu/tobacco/docs/kxxj0061

230 Industry Documents Library. 840000 operational plans. 1983 https://www.industry documentslibrary.ucsf.edu/tobacco/docs/kqmf0134

231 Pm PM, Murphy M. Promotional pack sizes. 1982 https://www.industrydocument slibrary.ucsf.edu/tobacco/docs/mkhc0022

232 Industry Documents Library. Idaho. 1982 https://www.industrydocumentslibrary.ucsf. edu/tobacco/docs/yhdd0125

233 Industry Documents Library. State restrictions on sample pack sizes. $1981 \mathrm{https}: / /$ www.industrydocumentslibrary.ucsf.edu/tobacco/docs/ghdd0125

234 Pm PM, Murphy M. State sampling — marketing restrictions. 1982https://www.indu strydocumentslibrary.ucsf.edu/tobacco/docs/jhdk0129

235 Industry Documents Library. Kool 830000 Hispanic marketing \& operational plans. 1983 https://www.industrydocumentslibrary.ucsf.edu/tobacco/docs/ xtky0143

236 Research BM. Barclay awareness and attitude study (San Francisco/Witchita) analysis post wave II. 1985 https://www.industrydocumentslibrary.ucsf.edu/tobacco/docs/ hxpw0146

237 Industry Documents Library. Barclay 820000 strategic marketing plan. 1982 https:// www.industrydocumentslibrary.ucsf.edu/tobacco/docs/jnnn0139

238 Cook BL, Wayne GF, Keithly L, et al. One size does not fit all: how the tobacco industry has altered cigarette design to target consumer groups with specific psychological and psychosocial needs. Addiction 2003;98:1547-61.

239 Greenland SJ. Cigarette brand variant portfolio strategy and the use of colour in a darkening market. Tob Control 2015;24:e65-71.

240 Hyland A, Higbee C, Li Q, et al. Access to low-taxed cigarettes deters smoking cessation attempts. Am J Public Health 2005;95:994-5.
241 Chaloupka FJ, Straif K, Leon ME. Effectiveness of tax and price policies in tobacco control. Tob Control 2011;20:235-8.

242 Reid JL, Hammond D, Boudreau C, et al. Socioeconomic disparities in quit intentions, quit attempts, and smoking abstinence among smokers in four western countries: findings from the International Tobacco Control Four Country Survey. Nicotine Tob Res 2010;12(Suppl):S20-33.

243 Chaloupka FJ, Warner KE. The economics of smoking. Culyer JPN AJ, ed. Handbook of Health Economics. 1.1 edn: Elsevier, 2000:1539-627.

244 National Cancer Institute and Centers for Disease Control and Prevention. Smokeless tobacco and public health: a global perspective. Bethesda, MD: U.S. Department of Health and Human Services, Centers for Disease Control and Prevention and National Institutes of Health, National Cancer Institute, 2014. Report No: NIH Publication No. 14-7983.

245 Chaloupka FJ, Tauras JA, Grossman M. Public policy and youth smokeless tobacco use. South Econ J 1997:64:503-16.

246 Moodie C, Ford A, Mackintosh AM, et al. Young people's perceptions of cigarette packaging and plain packaging: an online survey. Nicotine Tob Res 2012:14:98-105.

247 Chaloupka FJ, Cummings KM, Morley CP, et al. Tax, price and cigarette smoking: evidence from the tobacco documents and implications for tobacco company marketing strategies. Tob Control 2002;11(Suppl 1):162-72.

248 Xu X, Pesko MF, Tynan MA, et al. Cigarette price-minimization strategies by U.S. smokers. Am J Prev Med 2013;44:472-6.

249 Carter SM. The Australian cigarette brand as product, person, and symbol. Tob Control 2003;12(Suppl 3):iii79-86.

250 Wertenbroch K. Consumption self-control by rationing purchase quantities of virtue and vice. Marketing Science 1998;17:317-37.

251 Marti J, Sindelar J. Smaller cigarette pack as a commitment to smoke less? Insights from behavioral economics. PLoS One 2015;10:e0137520.

252 Coelho do Vale $R$, Pieters $R$, Zeelenberg $M$, et al. Flying under the radar: perverse package size effects on consumption self-regulation. $J$ Consumer Res 2008;35:380-90. 